THE

\title{
JOURNAL OF GEOLOGY
}

NOVEMBER-DECEMBER, I896.

\section{THE AGE OF THE AURIFEROUS GRAVELS OF THE SIERRA NEVADA.' WITH A REPORT ON THE FLORA OF INDEPENDENCE HILL. ${ }^{3}$}

IT is the purpose of this paper to attempt to fix more definitely than has hitherto been done the age of the auriferous, detrital rocks of the Sierra Nevada, resting uncomformably on the bed rock series, generally at considerable elevations above the present drainage and covered by volcanic flows. This series is commonly designated as the "Auriferous Gravels." It is also the purpose to indicate briefly the more salient features of the Cretaceous and Cenozoic history of the Sierra Nevada. The results are the outcome of a study of the range between the parallels of $38^{\circ} 30^{\prime}$ and $39^{\circ} 30^{\prime}$, extending over a number of years, and are to be set forth more fully in a bulletin now in preparation.

The auriferous gravels have been carefully studied by Professor Whitney, who determined them as fluviatile deposits and assigned to them a Pliocene Age, basing his conclusions chiefly on the palæobotanical studies of Professor Lesquereux. At the same time Professor Whitney states that very probably auriferous gravels may have accumulated during the whole of the Tertiary period. On the maps of the United States Geological

I By WALDEMAR LINDGREN.

${ }^{2}$ By F. H. KNowlton.

3 Published by permission of the Director of the United States Geological Survey.

Vol., IV, No. 8. 
Survey by Messrs. Turner and Diller and myself, the auriferous gravels have been indicated as "Neocene," including under this name the Miocene and the Pliocene. The same authors have correlated the lacustrine or brackish Ione formation along the western base of the Sierra with the fluviatile auriferous gravels on the flank of the range, and the two former authors have considered the age of both as probably Miocene, ${ }^{\mathrm{T}}$ basing their conclusions upon the more recent palæobotanical determinations of Professors Leo Lesquereux, Lester F. Ward, and F. H. Knowlton. Recently Professor Lawson ${ }^{2}$ accepts Professor Whitney's determination of the auriferous gravels as Pliocene and thinks that the determination of the eroded surface on which rest the Ione formation and the auriferous gravels, as Miocene, may be in need of revision.

\section{STRATIGRAPHIC RELATIONS OF THE AURIFEROUS GRAVELS.}

The investigations of the United States Geological Survey have fully confirmed the earlier results as to the fluviatile character of the auriferous gravels over the whole flank of the Sierra Nevada above an elevation of a few hundred feet above the present sea level. Along the western base and at the northern end the auriferous gravels merge into brackish and lacustrine deposits. Along the western base the latter have been but little disturbed, while, according to Mr. Diller, they have experienced a considerable elevation at the northern end of the range. In a former publication ${ }^{3}$ I have indicated the direction and the grade of the channels over a part of the western slope and investigated the character of the surface on which the gravels rest. The surface is that of a gently sloping, greatly eroded mountain range, but by no means reduced to a base level and not even to be considered as a peneplain. Only on the

x 8th Ann. Report U. S. Geol. Survey, p. 420.

I4th " " " " " "

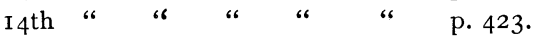

American Geologist, Vol. XV, June I895, p. 375.

${ }^{2}$ Bull. Dep. Geol., Univ. Calif., Vol. I, No. 4, p. I 57.

3 Bull. Geol. Sci. Am., Vol IV, p. 270. 
middle and lower slopes of this range did the gravels accumulate.

In the principal broad Neocene river valleys one may generally distinguish the following formations:

\section{A. The Ante-Volcanic Deposits.}

I. The deep gravels. - These, usually hard and compact, coarse gravels fill the deepest trough-shaped depressions to a maximum depth of about 200 feet, usually 100 to I 50 feet.

2. The bench gravels.-Covering the deep gravels and attaining a maximum depth of 300 feet, the bench gravels are spread out often to a width of one or two miles on the sloping shelves on both sides of the deepest trough. They are frequently very quartzose and more admixed with finer sediments than the deep gravels.

\section{B. The Volcanic and Inter-Volcanic Deposits.}

3. The rhyolitic tuffs.-Sweeping down the main river channels from the vents in the high Sierra, the flows of white rhyolite, accompanied by large masses of rhyolitic tuff, of clayey and sandy character, covered the bench gravels. These rhyolitic flows attain on the middle slopes a maximum depth of about 200 feet, while higher up they are much heavier. Much of this tuff is in the mining region designated as pipe-clay or chalk.

4. The gravels of the rhyolitic period.-The effects of the rhyolitic flows were to dam many lateral streams, thus causing immediate accumulations of gravels, clay, and sands. During the intervals between the rhyolitic eruptions the streams cut down new channels in the soft material and accumulated masses of gravel in their new beds. All these detrital masses of gravel, sand, and clay, generally of a finer character than the bench gravels, and usually containing rhyolitic pebbles, are designated as the "gravels of the rhyolitic period." In many places, such as Nevada City, Nevada county, and the Long Canyon divide, Placer County, the rhyolitic gravels attain a thickness of several hundred feet. 
5. The gravels of the inter-volcanic erosion period.-The interval separating the rhyolitic from the andesitic outbursts apparently differed in length at various points in the Sierra Nevada. While in some places, such as along the lower courses of the Middle and South Yuba, the andesitic tuffs lie almost conformably over the rhyolitic tuff, there are at other points, such as on the Forest Hill divide, near Placerville, and along the Mokelumne, indications of a relatively short period of a very active erosion, beginning immediately after the rhyolitic flows, or in some places shortly after the first flows of andesitic tuffs. This erosion was of a remarkably intense character, cutting sharp V-shaped canyons in new channels through the older beds, and in some places even down into the solid bed rock to a depth of about Ioo feet. This action is so very different from that of the ante-rhyolitic and rhyolitic streams that the inference is justified that just after the rhyolitic flows the tilting of the slope took place, or at least began. In the bottom of these sharply cut channels a few feet of gravel accumulated along stretches with less grade, while, where the gorges were narrow and the grade steep no detritus is found. These are the gravels of the inter-volcanic erosion period.

6. The andesitic tuffs and tuffaceous breccias.-The andesitic tuffs poured down the river valleys in the form of successive mud flows of enormous volume, at first as sandy and clayey masses, but later mixed with a great quantity of larger angular or subangular fragments of hornblende and pyroxene-andesite, at last covering a large part of the slope and forcing the rivers to seek entirely new channels.

Along the valley border the Ione formation corresponds to the ante-volcanic bench gravels along the old rivers in the Sierra. The oldest or deep gravels of the river courses correspond to the fluviatile deposits in depressions in the surface on which rests the Ione formation; in other words, before the Ione transgression the rivers extended westward, probably to the center of the valley. The volcanic period is, along the valley border, represented by a series of gravels, sands, and tuffs spread over the Ione formation. 
THE PAL EOBOTANICAL EVIDENCE OF AGE.

Almost the only means of determining the age of the auriferous gravels is afforded by the numerous plant remains which they sometimes contain. Remains of vertebrate animals have been found, but as Mr. H. W. Turner has pointed out, there is much doubt as to whether certain of the occurrences described by Whitney really belong to the auriferous gravels, so that this line of evidence does not at present lead to any satisfactory conclusions.

The age of the deep gravels.-No fossils of any kind have, as far as I am aware, been found in these beds. The coarse character of the gravels is largely responsible for this. As the bench gravels will be shown in the following pages to be of Miocene Age, the deep gravels are manifestly older, and some of them may be Eocene, but hardly older.

The age of the bench gravels.-The best and most extensive collections come from the upper part of the bench gravels, or from the very lowest part of the rhyolitic tuffs.

The Chalk Bluffs locality.-The largest collection examined by Professor Lesquereux was gathered by Mr. C. D. Voy, at Chalk Bluffs, near You Bet, Nevada county, and it therefore becomes desirable to indicate its exact horizon. You Bet is situated on the main channel of the Neocene South Fork of the Yuba, and the leaves occur at an elevation of about 3000 feet. The stratigraphic relations are extremely similar to those of Iowa Hill (Fig. I) a little further south on the drainage of the old American River. There are the same deep gravels and heavy spreading bench gravels, capped by rhyolitic tuffs and andesitic tuffaceous breccia.

A bluff of the volcanic beds has been exposed by the hydraulic mining operations, and owes its name to the brilliant white color of the rhyolite. The exact locality from which the leaves came is a matter of some doubt, and is now covered by sliding débris. I was told by residents that they occurred at a place near the top of the bench gravels just below the rhyolitic 
beds; on the other hand Professor Whitney states in his volume on the auriferous gravels that the matrix in which the fossils occurred was rhyolitic tuff. Professor Andrew Lawson kindly sent me some fragments of the matrix from the collection now preserved in the University of California. They are soft grayish to brownish compact clays which did not, under the microscope, give any evidence of volcanic origin; the extremely fine grain, may, however, have masked their original character. This much is certain that the fossils came from the uppermost bench gravels, or the lowest rhyolitic tuffs and about 500 feet above the bottom of the channel.

The Independence Hill locality.-In I89 I Dr. Cooper Curtice, on the request of Dr. G. F. Becker, visited many places in the gold belt to collect fossils. Among these were the Washington

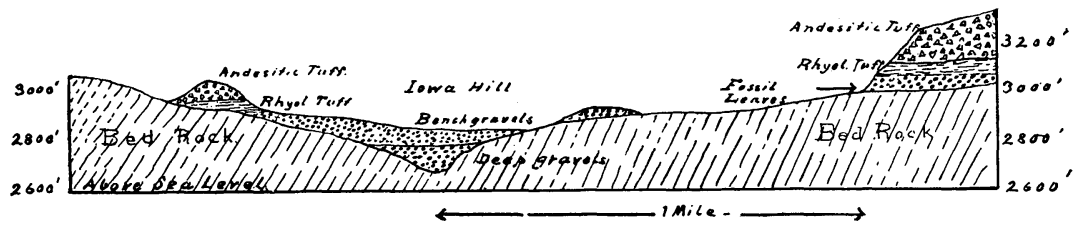

FIG. I. General cross-section at Iowa Hill.

gravel mine at Independence Hill, near Iowa Hill, Placer county. Mr. J. B. Hobson, the owner of the mine, first directed our attention to the occurrence. A very fine and extensive collection of fossil leaves was obtained. The leaves occur in a whitish or bluish consolidated clay or shale which at first is soft, but on exposure becomes moderately hard and brittle. This shale was interbedded with gravels near the base of the 200 feet high bluff produced by the hydraulic work. A glance at the section (Fig. I) shows that the lower part of the bluff forms a part of the bench gravels (2) which again are overlain by rhyolite tuff (3) and gravels of the rhyolitic period (4). The fossils consequently come from the uppermost gravels of the ante-volcanic period. Professor Knowlton after making a careful study of this collection, remarks on it as follows: "Dr. Curtice's is the first large collection of plants that has been obtained from the aurif- 
erous gravels since the material was collected which furnished the basis of Professor Lesquereux's investigations of this interesting flora. A number of smaller collections made from time to time by various members of the survey have also been studied by Professor Lesquereaux, but they were from isolated and separated localities and furnish comparatively little additional information as to the age of these deposits. The present excellent collection is therefore of special interest. The vegetable remains represented are in general very finely preserved and admit of careful and satisfactory study. Most of the species are represented by ample material and some of them, by a large series thus making possible a much more thorough biological study than could heretofore be made. Almost all of this material has been determined, the only portion remaining unidentified being a number of fragments and a few either with obscure impressions or with doubtful affinities.

The collection as outlined above, embraces fifty-six species of which number ten appear to be new to science. The new species belong to the following genera: Ariscemites, Ficus, Ulmus, Rhus, Zisyphus, Esculus, Castanea, and Viburnum.

These forms considered merely in the light of new species of course have little value in determining the age, but a more extended research through the literature on the subject than it has been possible to give at this time would undoubtedly bring out points of relationship or possibly of identity and they would then have a value as bearing upon the question of age. Until this can be done they must all be left out of consideration. As was to have been expected, a large number of the species were identified with those described by Professor Lesquereux in his paper on the flora of the auriferous gravels. Of the fifty-six species twenty have never been found in other deposits. Many of them were compared by Professor Lesquereux to living species and undoubtedly influenced him in deciding that the formation was of comparatively recent age. I have not had an opportunity of comparing these species myself, and until this can be thoroughly done they cannot be taken account of in the present connection. 
Twenty species have also been identified in other formations, the six remaining forms making up the fifty-six species being of doubtful affinities. The following hastily prepared table shows the distribution of those forms.

TABLE SHOWING IDENTIFICATIONS OF FOSSIL PLANTS FROM INDEPENDENCE HILL, CALIFOR NIA.

\begin{tabular}{|c|c|c|c|c|c|c|c|c|}
\hline Species & 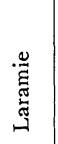 & 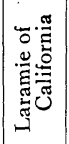 & 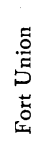 & 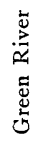 & 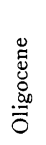 & 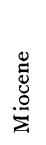 & 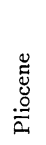 & Remarks \\
\hline 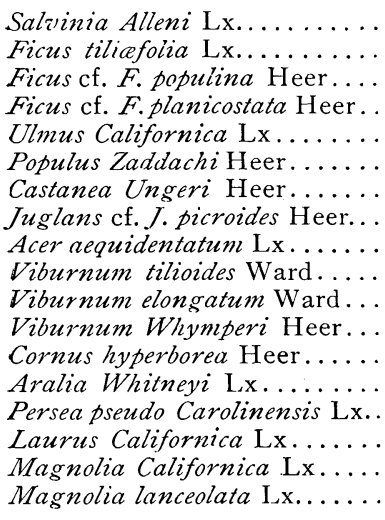 & \begin{tabular}{l|}
$\times$ \\
$\ddot{x}$ \\
$\cdots$ \\
$\ddot{x}$ \\
$\cdots$ \\
$\cdots$ \\
$\cdots$ \\
$\ddot{x}$ \\
$\cdots$ \\
$\cdots$ \\
$\cdots$ \\
$\cdots$ \\
$\ddot{x}$
\end{tabular} & 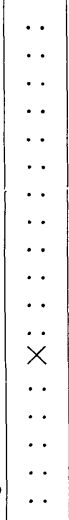 & $\begin{array}{l}\ddot{x} \\
\cdots \\
\cdots \\
\cdots \\
\cdots \\
\cdots \\
\ddot{x} \\
\ddot{x} \\
\times \\
\cdots \\
\cdots \\
\cdots \\
\cdots\end{array}$ & $\begin{array}{l}\times \\
\times \\
\times \\
\cdots \\
\ddot{x} \\
\cdots \\
\ddot{x} \\
\cdots \\
\cdots \\
\cdots \\
\cdots \\
\cdots \\
\cdots \\
\cdots \\
\cdots\end{array}$ & 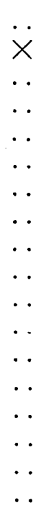 & $\begin{array}{l}\ddot{x} \\
x \\
\ddot{x} \\
\ddot{x} \\
x \\
x \\
x \\
\cdots \\
\cdots \\
\ddot{x} \\
x \\
x \\
x \\
x \\
x \\
\times \\
x\end{array}$ & $\begin{array}{l}\ddot{x} \\
\cdots \\
\ddot{.} \\
\ddot{x} \\
\times \\
\ddot{x} \\
\cdots \\
\cdots \\
\because \\
\ddot{x} \\
\times \\
\times \\
\times \\
x\end{array}$ & $\begin{array}{l}\text { Green River only. } \\
\text { Laramie only. } \\
\text { 3/4 Miocene. } \\
\text { 1/2 Miocene. } \\
\text { Miocene only. } \\
\text { Fort Union only. } \\
\text { Miocene sp. } \\
\text { 3/4 Miocene. } \\
\text { California only. }\end{array}$ \\
\hline
\end{tabular}

A study of this table shows that twelve species have been found in the Miocene in various parts of the world. Of this number five are almost exclusively confined to this horizon, and may be regarded as typical Miocene forms.

Only nine of the nineteen forms are found in the Pliocene, and two of these are from the so-called Pliocene of California and therefore have little weight. None of these nine species is confined to this horizon. It will be observed that five species are accredited to the Laramie; of this number two are from Cherry Creek, Oregon, the age of which is only provisionally regarded as Laramie, the probability being that it is younger. Another species, Viburnum Whymperi, is doubtfully identified in the Laramie, being a characteristic Miocene species. A single 
fragmentary leaf has been compared to Ficus planicostata Lx., a typical Laramie species, but the material is insufficient for a satisfactory determination. Ficus tiliafolia Lx. has also been found in the Laramie at Golden, Colorado, but its principal range is in the Miocene and Pliocene.

Cornus hyperborea was found by Lesquereux in California in strata said to be Laramie, but the evidence seems insufficient and the horizon is much more likely to be later.

The Fort Union group is presented by no less than four species, three of them belonging to the genus Viburnum, and one to Ficus, while five species are found in the Green River group (Eocene) with one species (Salvinia Alleni) heretofore entirely confined to it. Two species have also been found in the Oligocene. From this tentative review it is seen that all of the species having a distribution outside of the auriferous gravels belong to formations of Pliocene or older age; none of them are more recent or living. The number wholly or mainly Miocene considerably exceeds the number found in any other ho.izon, and none of the species are apparently confined to the Pliocene. While the evidence is not yet sufficiently worked out to permit a positive statement, it seems to point very clearly to the Miocene Age of this deposit.

The following is a list of fossil plants found at Independence Hill. Quite a number are without doubt new to science, but as they have never been published I have simply given the generic name.

Salvinia Alleni Lx.

Ariscemites n. sp.

Ficus sordida $\mathrm{Lx}$.

Ficus asiminafolia $\mathrm{Lx}$.

Ficus tiliafolia Al. Br.

Ficus sp.

Ficus sp.

Artocarpus Californica Kn.

Ulmus Californica Lx.

Ulmus officinis Lx.

Ulmus pseudo-fulva Lx.
Ulmus n. sp.?

Ulmus fruit of.

Platanus appendiculata Lx.

Juglans egregia Lx.

Juglans sp.?

Hicoria? fruit.

Salix Californica Lx.

Populus Zaddachi Heer.

Betula aqualis Lx.

Betula or Alnus, fruit.

Quercus convexa Lx. 
Quercus distincta $\mathrm{Lx}$.

Quercus elanoides $\mathrm{Lx}$.

Quercus castanopsis? Lx.

Quercus Boweniana Lx.

Castanea Ungern. Heer.

Castanea n. sp.?

Castanopsis chrysophylloides Lx.

Corylus sp.

Magnolia lanceolata $\mathrm{Lx}$.

Magnolia Californica Lx.

Liquidambar, fruit.

Acer aquidentatum Lx.

Acer fruit.

Rhus myricafolia $\mathrm{Lx}$.

Rhus dispersa Lx.

Rhus Boweniana Lx.

Rhus n. sp.
Assculus n. sp.

AEsculus fruit.

Aralia Whitneyi Lx.

Aralia angustiloba $\mathrm{Lx}$.

Laurus Californica Lx.

Persea pseudo-Carolinensis Lx.

Zizyphus piperoidas Lx.

Zizyphus n. sp.

Viburnum tilioides Ward.

Viburnum Whymperi Ward.

Viburnum elongatum? Ward

Viburnum n. sp.

Viburnum fruit.

Cornus ovalis Lx.

Cornus hyperborea Heer.

Cornus n. sp.

Cercocarpus antiquus $\mathrm{Lx}$.

This list, it should be remembered, is tentative and is likely to be modified by further collections or possibly to some extent by additional study.

The age of the Ione formation. - The flora found in the Ione formation is rather meager. North of $39^{\circ} 30^{\prime}$ Messrs. Diller and Turner ${ }^{\mathrm{I}}$ have at several places found a scant flora considered by Professors Lesquereux, Ward and Knowlton to be of Miocene age and contemporaneous with the auriferous gravels. At Volcano hill, Placer county, H.W. Turner found fragments of leaves partly identical with those from Chalk Bluffs and Professor Knowlton considers them as probably Miocene.

In the Marysville Buttes, in the center of the Sacramento Valley I found a series of beds resting on the Tejon which I correlated with the Ione formation. In these a number of shells were found which Messrs. Stearns and Dall regarded as Miocene. The following forms were identified:

Crassatella Collina Conr.

Venericardia borealis Conr.

Verticardia? sp.

Acila castrensis Hinds.
Macoma sp.

Tapes (Cuneus) sp.

Saxidomus sp.

Cardium modestum.

IJ. S. Diller, Lassen Peak District, 8th Ann. Rep., U. S. G. S., p. 4I9. H. W. TURner, Rocks of the Sierra Nevada, I4th Ann. Rep., U. S. G. S., p. 462. 
Liocardium apicinum $\mathrm{Cpr}$. Fusus (Exilia) sp.

Galerus sp.

Independently, however, of this flora and fauna the stratigraphic evidence connecting the Ione formation with the antevolcanic bench gravels is positively and unmistakably indicated, and the two can at numerous points be shown to run over one into another; thus south and north of Rocklin, Placer county, and at the mouth of the Yuba as well as north and south of the area here specially treated. As the bench gravels, the Ione formation is overlain by rhyolitic and andesitic tuffaceous beds.

Age of the rhyolitic tuffs and associated gravels. - These are but slightly younger than the bench gravels, but no flora has been studied from them unless that of the Chalk Bluffs be partly from that horizon.

Age of the gravels of the intervolcanic erosion period.-Leaves have been collected by Diller from Monte Cristo gravel mine, Spanish Peak, Plumas county, which are from a bed overlain by andesite and, according to Turner, pretty certainly later in age than the white quartz gravels, although not positively representing the period of the andesitic flows. ${ }^{x}$ In Mohawk Valley Turner has collected leaves from the Neocene lake beds containing rhyolitic fragments and covered by andesitic tuffs. According to Professor Knowlton ${ }^{2}$ these are closely related to the flora of the auriferous gravels. The leaves from Tuolumne Table Mountain are also, according to Turner, later than the auriferous gravels proper.

Among the localities described by Professor Whitney is Bowen's tunnel, Placer county, two miles north of Michigan Bluffs. Regarding this place, Professor Whitney writes, using the notes of Goodyear (Auriferous Gravels, p. 93). "The gravel averages a foot or two in the middle of the channel. Over the gravel is first a mass of "chocolate", (a brown consolidated clay, probably a volcanic mud) "from one to four feet in thickness; above this is the gray cement" (andesitic tuff)

${ }^{x}$ Am. Jour. Sci., June 1895.

${ }^{2}$ Fourteenth Ann. Rep., U. S. G. S., p. 466. 
"similar to that of the Reed mine near Deadwood. This "chocolate' contains leaves of deciduous and coniferous trees in tolerably good preservation." Now, Bowen's channel, correctly described above, is a typical example of the narrow valleys eroded shortly before the main andesitic outflows, and its flora is distinctly later than that of the Chalk Bluffs and Independence Hill and just antedates the main andesitic tuffaceous breccia flows. Lesquereux ${ }^{\mathrm{I}}$ describes the following species from this locality :

Quercus Boweniana Lx. Resembles certain living Mexican forms.

Rhus Boweniana Lx.

Zanthoxylon diversifolium $\mathrm{Lx}$. Closely related to Z. integrifolium Heer (Swiss Miocene).

Acer vitifolium Al. Br. (Swiss Miocene).

The conifer leaves, mentioned by Whitney, do not appear to have been determined. Though meager, this flora is evidently closely connected, if not identical with that from the bench gravels and is probably Miocene. Still another locality mentioned by Professor Whitney is that of North Fork tunnel near Forest City, Sierra county. From the description of Professor Pettee (Auriferous Gravels, p. 437) it appears that the leaves found occurred in a sandy clay resting on a gravelly "cement" and directly covered by andesitic tuff. It is not quite clear whether by this "cement" is understood a volcanic tuff, but in any case it seems plain that the leaves could have antedated the andesitic tuff but a short time. This occurrence, which is considerably above the deepest gravels of the vicinity and not now accessible should probably also be connected with the inter-volcanic period of erosion. The elevation of this locality is nearly 5000 feet. The leaves are species of Quercus and Acer and Lesquereux remarks that it is Miocene by one species of Quercus and one of Acer, while it also has of each of these one species identical or closely resembling certain living Mexican forms.

While the flora of the gravels of the inter-volcanic erosion

r Report on the Fossil Plants: Appendix to Whitney's Auriferous Gravels. 
period is scant and no positive conclusions as to age can be drawn from it, it must be conceded that it is very closely allied to that of the bench gravels. While more extensive collections might show it to be of Pliocene age, yet the characteristic forms contained in it prove that up to the beginning of the rapidly succeeding andesitic flows there was no great change of climate.

Age of the andesitic flows. - Mr. Turner has at various points found fossil wood in the andesitic tuffs (Alpine county, elevation 7000 feet) which Professor Knowlton has identified as coniferous and designated as Cupressinoxylon and Pityoxylon. ${ }^{\mathrm{x}}$ No trees referable to the former genus occur at this elevation at the present time, from which it may be inferred that the climate during the andesitic period was milder than now.

To recapitulate, the deep gravels are probably of Eocene or Lower Miocene Age, the bench gravels and the rhyolitic tuffs are with considerable certainty of Miocene, probably Upper Miocene Age. The age of the gravels of the inter-volcanic erosion period and of the andesitic tuff is not established beyond doubt, but probably belongs to the lower Pliocene or Upper Miocene. The eroded surface upon which the auriferous gravels were deposited was consequently produced either during the earliest Miocene or during the Eocene.

It is of interest to note that Professor Knowlton in his extended studies of the floras of the Yellowstone National Park, ${ }^{2}$ has found a flora which he calls the Lamar flora and refers to the Upper Miocene; this flora he states bears a very close resemblance to that of the auriferous gravels.

REVIEW OF THE POST-JURASSIC HISTORY OF THE SIERRA NEVADA. ${ }^{3}$

In the following lines a short summary is given of the different phases of the history of the Sierra Nevada between the

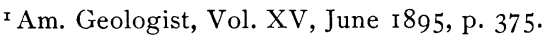

${ }^{2}$ Arnold Hague, The Age of the Igneous Rocks of the Yellowstone National Park, Am. Jour. Sci., June 1896, p. 452.

3 Unless otherwise stated, the results in this paper have only reference to the belt here studied. Many of them will be applicable to the whole range, but this needs confirmatory study. 
parallels of $38^{\circ} 30^{\prime}$ and $39^{\circ} 30^{\prime}$. Space forbids in this place anything but a mention of the results attained.

The early Cretaceous.- The grand features of the initiation of the Cretaceous were the plication and welding of the Mariposa beds with the older sediments, active eruptions continued from the Jurassic period of the lofty volcanoes along the foothills, then the seashore, and the intrusion, in the foundations of the range, of enormous masses - batholites - of dioritic and granitic magma. Of the mountain range occupying the site of the Sierra Nevada at this time we know but little. The Sierra Nevada and the Great Basin were evidently not differentiated. A very active erosion planed down this range to a peneplain or at least to a comparatively gentle topography. At this time, probably shortly before the deposition of the Chico Cretaceous, the first break took place, separating the Sierra Nevada from the interior basin.

The orogenic disturbance was probably of a twofold character. It included the lifting up of the whole region between the Wasatch and the Pacific in arching form, and a simultaneous breaking in and settling down of the higher portions of the arch. Thus the Sierra Nevada crust fragment was formed, the larger part of which has ever since remained a comparatively rigid block. Along the eastern margin the system of fractures was outlined (see Fig. 2) which towards the close of the Tertiary was to be still further emphasized. The faults along these fractures were largely of normal character. The movement did not take place evenly along all of these faults, hardly any occurring in some places, while along other parts of the system the whole of the fault was confined to this time.

The main break occurred along a line extending from near Markleeville by Genoa up towards Reno, and the displacement reached a maximum of 3000 feet. The fault along the western side of Antelope Valley, which probably will prove to be continuous with the Mono Lake fault, also appears to have been broken at this time. But the large crust block west of this first mentioned line proved too great to sustain itself, and a large part 
of it, bordered by parallel fault lines, sank down. This sunken area is now indicated by Lake Tahoe and by its continuation northward, the Sierra Valley, only separated from each other by masses of Tertiary lavas. The Tahoe-Sierra Valley "Graben"

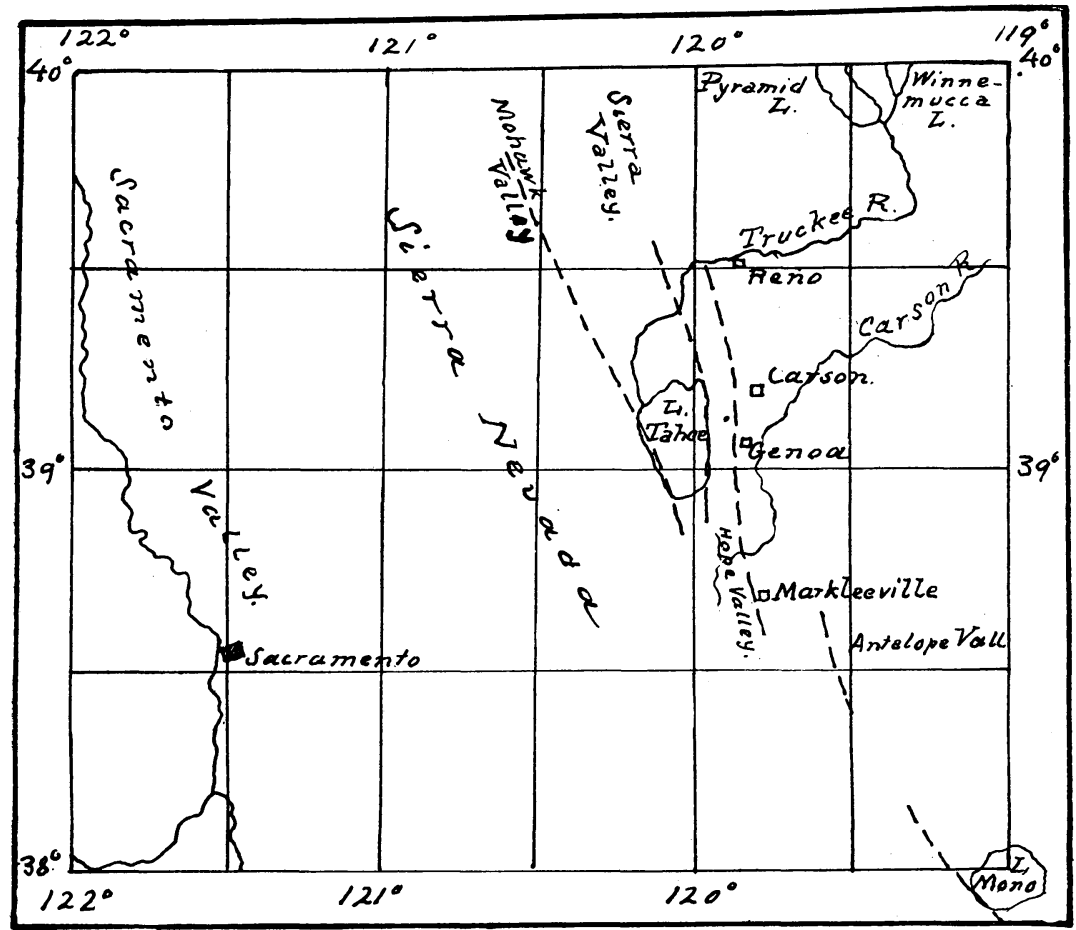

FIG. 2. Fault lines of the Sierra Nevada.

or "Moat"' (the later word hesitatingly proposed as an English equivalent), is bordered on the west by the fault line beginning at Mt. Tallac, and extending by Donner, Independence and Weber lakes up towards Sierra Valley and Mohawk Valley. At this latter place the investigations of Mr. Turner indicate that the displacement may to a great extent at least be of Miocene Age. On the east it is bordered by the very distinct fault-line extending along the east side of Lake Tahoe up east of Boca and towards the east side of Sierra Valley. The long ridge between 
the latter fault and the main break facing the Great Basin has very pronouncedly the character of a "Horst" or "Buttress" (the latter expression has been suggested by Mr. S. F. Emmons) - a block standing between two sunken areas.

This view then implies a gradual arching of the whole western part of the continent and a simultaneous sinking of parts of this uplifted crustal fragment, by reason of gravity, along longitudinal fractures. It is in close conformity with the previously announced views of King and Le Conte.

The newly formed block of the Sierra Nevada was at once attacked by the erosion; at first probably narrow canyons were cut in it, similar to those of today, though not so deep.

Chico period; close of the Cretaceous.-At this time the shore line along the western base advanced eastward and reached at least an elevation of 300 feet above the present sea level, possibly considerably higher. The Chico sandstones were laid down on an uneven surface, the foothills showing a relief at least as prominent as those of today. This important event is referred to as the Chico transgression.

The Téjon period (Eocene).-During the Chico and the Téjon the erosion was steadily at work on the flank of the Sierra Nevada, the first deep canyons were widened to broad valleys in the lower and middle parts of the range, while still preserving their character nearer the crest. There is no evidence of any Eocene deposits along the valley border in this latitude, though marine Eocene occurs in the Marysville Buttes in the center of the Great Valley and also further south on the east side of the San Joaquin Valley. Sediments of this age may have been deposited between $29^{\circ} 30^{\prime}$ and $38^{\circ} 30^{\prime}$, but if so, subsequent erosion has removed them. An important period of erosion certainly intervened between the Chico and the Miocene, and it is probable that the Eocene shore line was situated somewhere between the first foothills and the Marysville Buttes. This erosion has removed the greater part of the Chico sandstone, so that the Miocene along the valley border in part rests on older rocks, in part on fragments of Chico sandstone. While remov- 
ing much of the Chico this. Eocene erosion did not cut deeply into the underlying older series of crystalline rocks. Certain of the lower auriferous gravels underlying the Ione formation near the valley border may be Eocene or early Miocene, and the same age may be assigned to the deep gravels of the upper stream courses.

The early Miocene period.-About the time of the upper Eocene or the lower Miocene, then, the shore line had retreated farwestward ; this is directly indicated by the occurrence of heavy stream gravels brought up by volcanic agencies in the Marysville Buttes along with estuarine Miocene beds, correlated with the Ione formation. These gravels carry comparatively coarse gold. The slope of the Sierra had assumed the topographic character which the Miocene and Pliocene deposits have preserved for our inspection. The foothill topography of this old eroded surface consisted of comparatively rough ridges, the level tops of which indicated the old Cretaceous peneplain. The middle slopes consisted of broad, partly longitudinal valleys and comparatively gentle slopes in which the old peneplain is noticeable only in places, such as Banner Hill, Oregon Hill, Osborne Hill, and the tops of the hills of the upper Georgetown divide. The upper slope reaching up the divide, situated very nearly where it is today, on the west side of Lake Tahoe, consisted of rougher and deeper valleys, divided by more or less level ridges, indicating the old Cretaceous peneplain. English Mountain, the Black mountains, Snow Mountain, Duncan Peak, Granite Chief, indicate this Cretaceous peneplain in Nevada and Placer counties; Mt. Tallac, the Pyramid Peak range, Robb's Mountain and many others indicate the same in El Dorado county. The relation of the two eroded surfaces, the Cretaceous and the Miocene, is clearly discernible from any point in the lower foothills looking up toward the summit of the range. Above the deep canyons of the modern gorges extend the broad, flat lava plateaux capping the separating ridges and looking very much like an old base level. These lava flows cover the comparatively gentle topography of the Miocene valleys. Above them rise the peaks 
and ridges just mentioned, and indicate with their level sky line the extend of a far older eroded surface, uplifted and dissected long before the auriferous gravels were deposited or the lava flows extruded.

The later Miocene period (the Ione formation).-This is the period of the auriferous gravels par excellence. Stream gravels had already formed to some extent in the lower reaches and deepest parts of the river valleys, but the greatest masses were accumulated during this period.

The shore line again moved eastward up to an elevation of at least 400 feet above the present sea level and a heavy series of sediments was laid down along the foothills which rose with decided relief above the waters of the gulf; this may be referred to as the Ione transgression. Only in the northern and middle part of the range did the gravels attain their maximum depth. One of the probable causes leading to their deposition has been indicated by $\mathrm{Mr}$. J. S. Diller, ${ }^{\mathrm{x}}$ who holds that disintegration exceeded transportation at the close of the Eocene and beginning of the Miocene, and that consequently the surface was covered with a deep mantle of decomposed material; during the Miocene a slight uplift increased the erosive power of the streams and swept the detrital matter into the river courses. This is very probably a correct explanation, although perhaps not the only one. It seems that the steep foothill ranges may have acted the part of barriers restraining the gravels in the valleys of the middle slopes. To this the heavy accumulations along the American and Yuba River on the middle slope is in part due.

Close of the Miocene; beginning of the Pliocene. The eruption of rhyolite and andesite near the crest of the range closed the gravel period. At some time during the volcanic period, probably in the interval between the rhyolitic and the andesitic flows, occurred a new break along the eastern base of the Sierra. The principal movement in this latitude took place along the old fault-line extending from Verdi, Nevada (ten miles west of Reno), down towards Markleeville, while along the fault-lines

${ }^{1}$ I 4 th Ann. Report U. S. G. S., p. 427. 
on both sides of Lake Tahoe little or no movement seems to have taken place. Near Verdi the displacement was probably smaller than further south. There is, along the first line, excellent evidence of the amount of the displacement. It probably did not much exceed 2000 feet, while the aggregate amount of both the late Cretaceous and the Miocene displacement is about 5000 feet near the latitude of the little town of Genoa, south of Carson. The best evidence of this displacement is found in the drainage of the West Fork of the Carson River, which from a meandering course in Hope Valley, in Alpine county-the topography of which accurately represents the pre-volcanic Miocene surface-breaks through the eastern scarp in a wild canyon of extremely steep grade, to again resume its meandering course in the Carson Valley 2000 feet lower.

Near the crest the range is at many places, as first pointed out by Dr. G. F. Becker, ${ }^{\text {I }}$ intersected by a system of joint planes on which small movements have taken place, which may aggregate to considerable amounts. These joint systems, which probably were produced about the close of the Neocene, appear to accompany and supplement the large normal faults at the eastern base.

To sum up, the topography about Lake Tahoe has remained similar to its present form probably since the close of the Cretaceous, while a late Miocene or Pliocene fault of 2000 feet has been formed along the east side of the buttress lying to the east of Lake Tahoe. The displacement here indicated is less by several thousand feet than that shown by the grade of the Neocene rivers as outlined in a previous paper; this strengthens the belief that we have here to deal with a composite movement, one upward affecting a large area, and one downward consisting of local sinking of moats. In comparing this region with that north of $39^{\circ} 30^{\prime}$ it should be borne in mind that, according to the best evidence, the northerly part during the gravel period stood at considerably lower elevations than the section about Lake Tahoe, as indicated among other things by the absence of

${ }^{x}$ Bull. Geol. Soc. Am., Vol. II, pp. 49-74. 
gravels at the latter vicinity and the abundant occurrence of them northward. The relative post-Miocene uplift has consequently been larger northward. During the gravel period a drained lake probably occupied the Tahoe-Sierra Valley moat. During the volcanic period Tahoe became separated from Sierra Valley by masses of andesite. Separate lakes covered Sierra Valley, the Boca-Truckee Valley, Tahoe and Mohawk valleys. Carson Valley east of the Genoa buttress was also occupied by a lake during the volcanic period, as was the vicinity of Verdi and Reno. During the tilting of the Sierra Nevada that crustal block did not act as a rigid mass, but was slightly deformed and arched, as indicated from a study of the Neocene river grades. ${ }^{x}$

Along the western foot of the range a retreat of the shore line occurred during the andesitic eruption as indicated by the unconformity separating the andesitic beds from the Ione formation and by another dividing the Pleistocene from the Ione and the volcanic beds.

The Pleistocene period.-The last andesitic flows are supposed to mark the close of the Pliocene in the Sierra Nevada. This is a somewhat uncertain line as to its exact age, but it is the only one which can be drawn without creating artificial distinctions. It is true that in referring the Ione formation to the Upper Miocene and drawing the line between the Neocene and the Pleistocene at the close of the tuff and breccia flows, the line limit allotted to the Pliocene becomes somewhat restricted, the volcanic period, as above observed, being of comparatively short duration. It is not improbable that the earlier part of the Pleistocene of the Gold Belt maps includes some of the Pliocene as outlined at other localities in the United States. The Pleistocene of the Gold Belt maps includes one long period of extremely active erosion, chiefly characterized by canyon-cutting; during this time another advance of the shore line took place; the Great Valley being at this time a lake, the highest elevation of whose shores, well marked by bodies of gravel, extended 400 feet above

I Two Neocene Rivers, Bull. Geol. Soc. Am., Vol. IV, p. 297. 
the present sea level. Mr. L. F. Ransome ${ }^{x}$ has expressed a belief that the Great Valley during the early Pleistocene was chiefly above water, though transient lakes might have existed. An extensive acquaintance with the formations along the Sierra foothills can hardly fail to convince anyone of the reality of the Pleistocene body of water extending up to the level indicated, though for the later part of the Pleistocene after the drainage of the lake by the subsidence of the region about San Francisco, ${ }^{2}$ Mr. Ransome's view is probably correct. A subsidence of only 50 feet would at the present time create a very large lake in the valley.

During the earlier and middle Pleistocene many minor eruptions of basalt took place, chiefly near the crest of the range. Lake Tahoe had first been dammed up by andesite during the latter part of the Neocene and during the earliest Pleistocene, its outlet, the Truckee River, cut a canyon through the andesite and through the northern continuation of the great buttress east of the lake. In middle Pleistocene time this canyon was again dammed up by a basaltic eruption, and again the lake cut an outlet through this second dam.

The second division of the Pleistocene period comprises the glaciation of the High Sierra, the drainage of the lake of the Great Valley and corresponding formations of fluviatile deposits.

During the glacial period the whole crest-region of the Sierra was covered with a continuous sheet of ice, névé and snow from which glaciers extended down along the principal river courses. The glacial basins were swept bare, the morainal débris accumulating at lower elevations, around the projecting ice tongues. The block east of Lake Tahoe and in fact the whole eastern slope was only glaciated to a small extent. The outlet of Lake Tahoe, the canyon in andesite between Tahoe City and Truckee City, has apparently never been filled with glaciers though ice streams from lateral canyons reached it in one or two places. Lake Tahoe does not appear to have been filled with glacial ice at any time.

${ }^{x}$ Bull. Dept. Geol. Vol. I, No. I4, p. 386.

${ }^{2}$ Cf. A. Lawson, Univ. Calif. Bull. Dept. Geol. Vol. I, No. 8, p. 266. 
The largest glaciers were found on the headwaters of the Yuba and the American rivers. The lowest elevation at which glacial traces have been found on the western slope is about 3500 feet. The third period, the present, is marked by the disappearance of the glaciers and by the continued formation of fluviatile deposits in the Great Valley.

It is not believed that, during the early Pleistocene any marked orographic changes took place along the eastern base of the Sierra. In very recent times-after the glaciation-a renewed faulting is noticeable at many places, such as at Owen and Mono lakes and near Genoa south of Carson, Nevada. At the later place the displacement is about 40 feet. Very strong springs, many of them hot, are located along the foot of the scarp, which is extremely sharply marked. As at Mono Lake ${ }^{x}$ the deepest depression-here the Carson River-closely hugs the escarpment for considerable distance in spite of the active erosion and the large amount of material transferred to the valley from the escarpment. This appears to be a strong argument in favor of the view that the eastern block-the Carson Valley-is sinking, instead of the western block-the mountain scarprising.

The similarity of these conditions with those at the foot of the Wasatch, so admirably described by Mr. G. K. Gilbert, certainly appears very striking.

Recently Mr. F. L. Ransome has published an interesting criticism of the theory of isostacy as applied to the interior valley of California ${ }^{2}$ in which he arrives at the conclusion that the facts do not support the theory, in the case of the Great Valley, a conclusion which appears well justified. Mr. Ransome's argument could, however, have been made much stronger. From the above, it is clear, that there have been at least three important transgressions separated by unconformities, representing periods of erosion, since the end of the Cretaceous. The rivers sometimes extended far into the valley, while at other times the

${ }^{r}$ I. C. Russell, U. S. G. S., 8th Rep., pp. 26I-394.

2 Univ. Calif., Bull. Dep. Geol., Vol. I, No. I4, pp. 37 I-428. 
shore line moved far eastward. Subsidence has certainly not kept equal pace with deposition in the Great Valley.

CORRELATION WITH THE BEDS OF THE COAST RANGES.

In a recent bulletin of the Geological Department of the University of California, Professor Lawson has described the Miocene, Pliocene, and the Pleistocene from various points along the coast, calling especial attention to the evidence of recent elevation as attested by the numerous beach lines at elevations up to I 200 feet. ${ }^{x}$ He has further described the Merced series from the San Francisco peninsula and the Wildcat series from the northern coast, identifying both as Pliocene, and deposited during the gradual subsidence of the coast preceding the recent uplift, marked by the beaches. He finds that the Miocene, as represented by the Monterey series is distinct from the Pliocene as represented by the Merced formation, and that the latter is separated from the former by a long period of depression. The Pliocene and the Pleistocene gradually merge into one another, and the somewhat arbitrary line between the two should be drawn at the upper part of the Merced series at a time when the shore line began to recede westward. In short,

${ }^{x}$ Bull. Dept. Geol. Univ. of Calif., Vol. I, No. 4, p. I48. Professor Lawson, in demolishing Professor Davidson's view of the beaches along the coast of California as formed by ice action, states that the only geologists who have observed and correctly interpretated them are Dr. Cooper (Geol. Cal., Vol. I, p. I84), in his observations on San Clemente Island, and A. Bowman, in describing the coast in the vicinity of San Francisco (Pros. Cal. Acad. Sci., July I, I872). This is evidently not quite correct. No geologist could for a moment mistake those beach lines, so plainly are they indicated, and we find, for instance, that W. P. Blake (Pac. R. R. Rept., Vol. V, p. 187) recognized a raised beach 300 feet above the sea at Monterey, and a general elevation of the coast. Dall found evidence of a post.-Pliocene uplift of 600 feet in the vicinity of San Diego (Proc. U. S. Nat. Museum, I878, Vol. I, p. 3). Mr. G. F. Becker recognized a recent elevation of the coast of at least 250 feet (Monograph XIII, U. S. G. S., p. 207) on the Sonoma coast. In 1888, in a paper on the Geology of Baja, California, by W. Lindgren (Proc. Cal. Acad. Sci., 2d ser., Vol. I, Part 2, p. I79) the terraces are referred to as follows: "The numerous oscillations of the shore line during post-Pliocene time are equally plain in Lower California, as along the coast north of it. . . . . The ancient shore lines are shown on Punta Banda (60. miles south of the Mexican line) as often well marked wave-built terraces;" four beaches were recognized, the highest at an elevation of 600 feet. 
the history of the coast ranges in later geological times would be as follows :

Miocene depression.

Post-Miocene uplift and long period of erosion.

Pliocene depression; filling of valleys and truncation of the mountain to an approximate peneplain; archipelagic coast line.

Pleistocene uplift; beach lines.

The age of the beds has been determined by their molluscan remains, a line of evidence not altogether satisfactory where Tertiary and recent beds are concerned as has been pointed out among others by Professor Lawson ${ }^{\mathrm{x}}$ and also by Professor W. H. Dall. ${ }^{2}$

The question now arises how the beds along the foot of the Sierra Nevada should be correlated with the beds of the coast ranges. Dr. Lawson, without hesitation, correlates the Merced series with the auriferous gravels of the Sierra Nevada, ${ }^{3}$ accepting Whitney's determination of them as Pliocene.

It has been shown in the preceding pages that the upper part of the ante-volcanic auriferous gravels correspond to the Ione formation, and both have on palæobotanic grounds been referred to the upper Miocene. It has also been shown that the flora of the volcanic period very closely resembles that of the Ione formation. A very similar flora has been described by Lesquereux from Corral Hollow and Kirker Pass near Mount Diablo, on the western side of the valley. ${ }^{4}$ The beds rest in apparent conformity on Miocene carrying Ostrea titan Conrad, are associated with molluscan forms determined by Gabb as Pliocene from the twenty-one species identified; and are capped by detrital andesitic beds.

The characteristic feature of this flora of the Ione and the auriferous gravels is that it is related in its general characters to that of a subtropical moist region analogous to the northern coast of the Gulf of Mexico. It contains genera such as

${ }^{2}$ Bull. Dept. Geol. Univ. Calif., Vol. I, p. 57.

${ }^{2}$ Bull. 84 , U. S. G. S., p. I 95.

3 Bull Dep. Geol. Univ. Calif., Vol. I, No. 4, p. I57. See also Vol. I, No. I, p. 56.

${ }^{4}$ H. W. Turner, Geol. Soc. Am. Bull., Vol. II, pp. 383-402. 
Quercus, Ficus, Juglans, Magnolia, Persea, Laurus, Cinnamomum, Paliurus, Zisyphus, etc. Contemporaneously with this flora the salt water extended eastward as far as Mount Diablo and northward probably as far as the Marysville Buttes.

There are some remains of plants in the Merced series, described by Professor Lawson. ${ }^{x}$ At the very base rests, on Mesozoic volcanic rock, a stratum of partly carbonized forest material from which abundant pine cones were collected; these were determined by Professor E. L. Green as Pinus insignis (Monterey pine), a species not widespread at the present day, but still growing abundantly dear Monterey; about the middle of the series little altered trunks of trees occur associated with cones determined as Pseudotsuga taxifolia (Douglas spruce), a species common in California at the present time. It is scarcely permissible to correlate these two floras. In the auriferous gravels there is not one species, according to Professor Knowlton, which can be undoubtedly identified with living forms, and moreover, the coniferæ are sparingly represented. Even conceding the possibility of a slightly cooler climate on the immediate seacoast, Professor Knowlton ${ }^{2}$ does not believe that these two different floras could have existed at the same time and in so close proximity to each other.

The correlation of the Merced and Wildcat series with the auriferous gravels does not then appear permissible. It seems that in the maps of the valley border of the Sierra Nevada, the arbitrary line between the Neocene and Pleistocene has been drawn considerably lower than the similar arbitrary line established by Professor Lawson at the top of the Merced series. In other words the Pleistocene as defined on the gold belt maps, occupies a considerably longer time than the Pleistocene on the coast as defined by Professor Lawson. The Merced series is probably contemporaneous with the early Pleistocene of the valley border.

A detailed examination of the western valley border in the vicinity of Corral Hollow and Kirker Pass would greatly eluci-

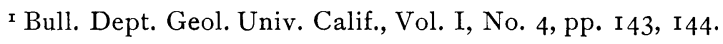

${ }^{2}$ Oral communication, February I896. 
date the question. Stratigraphic, floral and faunal evidence should as much as possible be considered together to obtain correct results.

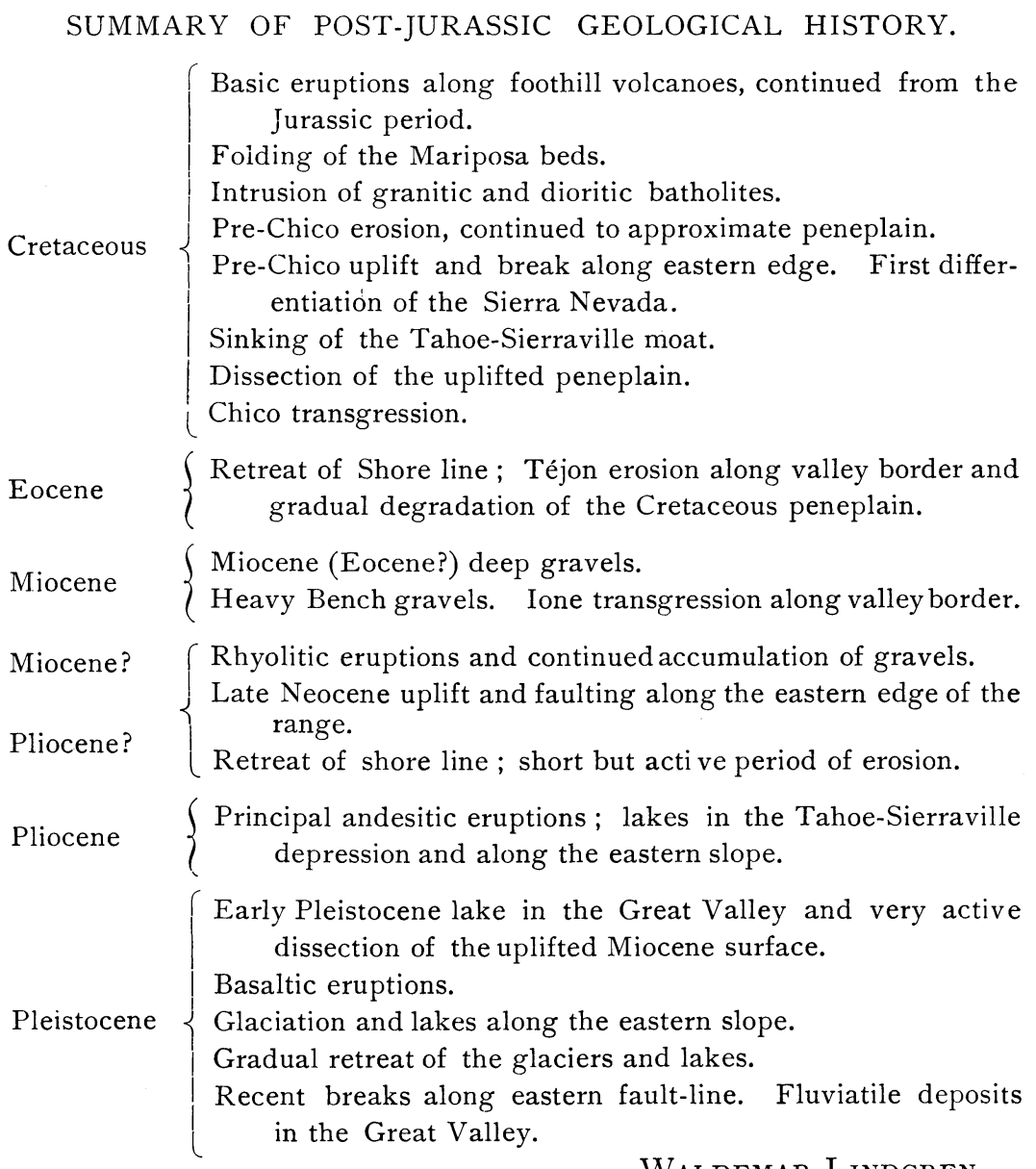

WALdemar Lindgren. 